Original Research Article

\title{
Analysis on the Reason and Influence of China's Money Supply after the Sub-prime Crisis
}

\author{
Weiwei Ji,Hongchao Yu,Deming Dong \\ Business School, Shanxi University of Political Science and Law, Shanxi, China
}

\begin{abstract}
In the global economic integration today, any economic turmoil will be in a very short period of time spread throughout the world. By the subprime mortgage crisis triggered by the 2008 US financial crisis, this will be more vividly. China's accession to the WTO, the economy has been with the global convergence, the economic crisis is bound to China's financial market to bring a turbulent. In order to stimulate China's economic recovery, the central bank to adopt a moderately easy monetary policy, a sharp increase in money supply. This paper mainly studies the influence of the increase of money supply in China after the subprime mortgage crisis, and explores the relationship between money supply and economic growth and inflation through quantitative and qualitative analysis. Finally, we summarize the results through the study.

KEYWORDS: money supply reasons, exploration, economic growth, inflation
\end{abstract}

\section{Introduction}

After the outbreak of the subprime crisis in 2007, with the spread of the crisis, the subprime mortgage crisis to varying degrees to bring shock to the rest of the world, in the subsequent rescue process, governments introduced a series of macroeconomic policy measures, including financial market rescue measures. China has formulated a moderately easy monetary policy according to its national conditions and has affected the economy by adjusting the money supply to improve the financial market environment in China by the economic crisis. Crisis

A Brief Introduction to the Economic Impacts and Monetary Policy Changes at Home and Abroad after the Financial

\subsection{Foreign economic conditions and monetary policy (in the United States as an example)}

The impact of the economic crisis on the US economy and the adoption of monetary policy

(1) The real estate bubble burst, real estate investment shrinking a serious drag on the US economy

US housing-related investments account for about $30 \%$ of US fixed asset investment, which has led consumers and investors to reduce their spending on housing and continue to slump in investment, directly affecting economic growth

(2) The decline in consumption to speed up the pace of the US economy down

Housing prices continue to fall, housing assets shrinking, the effect of diminishing wealth will inevitably have a negative impact on consumption. 'The stock market prices have also undergone a deep adjustment, residents of wealth has shrunk dramatically, which led directly to the US residents' willingness to consume and spending significantly reduced, Consumption fell sharply, macroeconomic growth affected '

(3) Confidence and trust crisis led to corporate financing difficulties, real economic investment dropped

By the impact of the real estate market downturn, US residential investment from 2006 began to drastically reduced

Continued negative growth 'In 2007, with the subprime crisis show, the sharp decline in the trend, which

Copyright (C) 2017 -. This is an Open Access article distributed under the terms of the Creative Commons Attribution-NonCommercial 4.0 International License (http://creativecommons.org/licenses/by-nc/4.0/), permitting all non-commercial use, distribution, and reproduction in any medium, provided the original work is properly cited. 
$16.3 \%$ in the first quarter and n. $8 \%$ in the second quarter, $20.1 \%$ in the third quarter, offer a total of $0.93 \%$ ! $-0.62 \%$ and a $1.05 \%{ }^{11} / 4$

(4) Manufacturing fell sharply

According to data released by the US Bureau of Demographic Statistics on October 4, 2007, US manufacturing is also out

(5) The unemployment rate hit a record high States

According to the US Department of Labor published on October 5, 2007 family survey data, August 2007 the United

The number of unemployed in the country was 7.097 million, compared with 720.7 million in September. 'After the subprime crisis, unemployment

Rate gradually deteriorated trend.

\section{US policy}

After the outbreak of the subprime mortgage crisis, the Fed first came forward and continued to use its skilled open market operations and cut interest rates and other means to try to inject the market for the effective operation of the liquidity and confidence 'the federal government followed up with the Federal Reserve to implement economic stimulus And financial rescue operations 'These actions involve financial rescue! Economic stimulus! Mechanism reform! International cooperation and many other aspects of which the main contents of financial rescue operations include: (1) Market capitalization and interest rate cuts (2) Institutional capital injection institutions are the following three For example, in March 2008, the Federal Reserve provided \$ 29 billion in loans to JPMorgan Chase to acquire Bear Stearns at the end of the year. 'Second, the acquisition of assets and capital injections, the first, the provision of funds to support institutional reorganization' Third, the nationalization '(3) investment bank transformation. The US Federal Reserve Board allows Morgan Stanley and Goldman Sachs Group to transform from investment banks to traditional bank holding companies '

\subsection{Domestic monetary policy}

\section{Impact of financial crisis on China and corresponding policies}

\subsubsection{Negative effects}

(1) The impact on China's banking industry

The major domestic banks to buy a total of about $\$ 20$ billion worth of US securities industry securities products 'As the US financial industry is facing a huge dilemma, the domestic financial institutions to buy securities products are facing a huge depreciation or even liquidation of the bad luck'.

(2) The impact on China's foreign trade

China's GDP in recent years to maintain rapid growth, cannot be separated from exports, investment and consumption of the three carriages pulled 'the US economy is weak. The financial situation continues to deteriorate, which is bound to impact on China's exports' 20091 September, the total import and export value of 155,580,000,000 US dollars, down $20.9 \%$. The financial crisis for the adverse effects of China's import and export is clearly revealed, the difference is only different degrees of the impact of different months.

(3) The impact of consumer confidence in China

Consumer expectations index since July 2008 peak since the continued decline in December fell to 100.8,

In April this year and fell to $89^{\prime}$

(4) The impact on China's investment

Many of the uncertainties and potential risks of the subprime crisis have led to a general rise in risk aversion. A general decline in confidence in economic growth will lead to a decline in business investment enthusiasm at the same time due to the deterioration of the external environment, foreign direct use of foreign capital weakened; international resource prices may be a big rebound, these factors will lead to business investment decline.

\subsubsection{Positive impact}

(1) External economic pressure reduction 
After the outbreak of the US financial crisis, especially since September 2008, China's external pressure has been significantly reduced. Although China's foreign trade orders have been reduced, but China's foreign trade disputes and friction cases are significantly reduced, while the appreciation of the renminbi pressure is also reduced.

(2) The external market environment improved

China's external market environment faced by the United States during the financial crisis has also eased, to improve China's international resource strategy is more favorable to the layout of China's inflationary pressures and improve the competitiveness of certain industries favorable.

(3) China's soft power can be improved

Crisis to improve the soft power of our country will affect the international political landscape adjustment 'The emergence of the US financial crisis, at least from the volume to change the Sino-US economic interdependence on the asymmetry of China's economic and stable development of the economy into a global economy and The international economic order of the stability of one of the important factors, which will not only increase China's future international economic affairs in the right to speak, but also substantive to promote high-level strategic dialogue between China and the United States play a positive role '

\subsubsection{China's monetary policy adopted}

China's economy in 2007 to mid-2008 experienced a high inflation, the corresponding implementation of the central bank tight monetary policy. In the second half of 2008, in order to cope with the spread of the financial crisis, China's monetary policy and emergency shift, the implementation of a moderately easy monetary policy to reduce the crisis on the real economy drag to stimulate the rapid economic recovery. On the other hand, 2007 is also the peak year of monetary policy adjustment, the annual deposit reserve ratio adjustment up to 70 times, this high frequency policy adjustment continued to 2008, which also marks the central bank to adjust the policy more Intensive and flexible. From July 2008 to the end of 2008, the central bank adjusted the macro-control measures of financial institutions, cut the deposit and loan interest rates three times, cut the deposit reserve ratio twice, abolish the credit planning of commercial banks, and guide the commercial banks to expand the total amount of loans.

\section{Changes in money supply and analysis of influencing factors}

\subsection{Analysis of changes in money supply}

The supply of money to a certain extent reflects the demand for purchasing capacity of the whole society, so the change of money supply can reflect the trend of social aggregate demand to a certain extent. Through the level of money supply and structural changes in the analysis, we grasp the crisis after the relative changes in China's total social demand.

\section{Analysis of changes in currency at all levels}

After the financial crisis in 2008, the absolute number of money supply at all levels gradually increased, but their growth rate is not fully synchronized. M0 growth rate showed a trend of increasing and decreasing, that is, from 2009 to 2011, the growth rate increased slowly, but the same period M1, M2 growth rate higher than the growth rate of M0, which is due to the currency 'multiplier effect' caused ; and in $2012 \mathrm{M} 0$ growth rate substantially reduced, reaching a three-year low of $9.48 \%$. In 2009, in order to cope with the financial crisis, China's capital increase in the three caliber of the year increased substantially. However, the growth rate of the three currencies was gradually slowed down.

From the changes in the amount of money can be found in China over the past few years is the implementation of loose monetary policy.

\section{Analysis of the Change of Money Supply Structure}

Three levels of money supply M0, M1, M2 reflects the size of the liquidity of different levels of currency, the size of the size of the currency, can reflect the overall liquidity of the size of the currency. The proportion of M0 in M1 decreased year by year after the financial crisis in 2008 and reached the lowest point of $17.45 \%$ in 2011 . The proportion of M0 in M2 declined year by year, from 6.68\% in 2008 to $5.31 \%$ in 2012. At the same time M1 in the proportion of M2 also showed a downward trend year by year, and in 2011 to 2012, a larger decline in 2012, the lowest value of $29.20 \%$. This shows that this period of China's money supply liquidity is too small, lack of economic boom. 


\subsection{Factors Influencing the Change of Money Supply}

There are many factors that have caused the change of money supply. Here, we mainly explore from the perspective of our monetary policy. In the global economic integration today, the subprime mortgage crisis to China's economic development has brought some impact, in order to deal with the financial crisis, our government has adopted a series of macro-control. China's monetary policy, whether from the role, the way or its role in all aspects of the occurrence of substantial changes in the control of the money supply is also changing, the central bank in the development and implementation of monetary policy is to continue to mature, the ability to carry out macro-financial control is also rising. The prospect of monetary policy is very difficult, because the monetary policy itself has a lag problem, coupled with the external shock to make accurate judgments, so although China in the BRIC countries inside the reaction is fairly fast, but afterwards there are still improved spaces.

\section{A theoretical analysis}

1. Credit Scale: Deposit Currency The bank's claim is formed through the central bank's provision of re-lending and rediscount to the deposit and currency bank. Beginning in 1998, the central bank abolished the loan quota management, the deposit and currency banks to further strengthen the balance of assets and liabilities management and risk management, deposit money Bank to the central bank to apply for re-lending and rediscount depends on its credit will. Economic prosperity or not, directly related to business and commercial banks will be willing to lend.

2. Deposit Reserve Policy: The deposit reserve system, as a basic system of commercial banks, is also one of the main tools for the implementation of monetary policy in China. Its monetary and monetary control, money market liquidity and interest rate regulation, Institutional sound operation, restrictions on currency substitution and capital flows into and out of the play an important role. In theory, to improve the statutory deposit reserve ratio, on the one hand directly to freeze the bank a certain amount of liquidity, on the other hand through the 'multiplier' effect, resulting in multiple contraction of the role of money. Relative to other monetary policy instruments, the statutory deposit reserve ratio is usually considered 'giant ax' or 'strong medicine'.

3. Financial revenue and expenditure: the central bank as a government bank, agent financial treasury is its important function. Therefore, all financial revenue and expenditure must be through the central bank account to achieve. The process of fiscal revenue means that money flows from a commercial bank account to a central bank account; the fiscal expenditure process means that money flows from a central bank account to a commercial bank account. The process of fiscal revenue is actually the process of ordinary currency contraction as the base currency; the fiscal expenditure process is actually the process of the expansion of the base currency into ordinary money, resulting in a decrease or increase in the multiple of the money supply.

Two empirical analysis

1. China's loan interest rate adjustment, expand the scale of credit.

Adjustment of deposit and loan interest rate of central bank from 2008 to

loan interest rate deposit rate

Adjustment time six months (inclusive) one year (inclusive) six months (inclusive) one year (inclusive)

2008.9.16 6.21\% 7.20\% 3.513 .87

$2008.10 .086 .12 \% 6.93 \% 3.243 .6$

$2008.10 .306 .03 \% 6.66 \% 2.252 .52$

2008.11.27 5.04\% 5.58\% 1.982 .25

$2008.12 .234 .86 \% 5.31 \% 2.22 .5$

$2010.10 .205 .10 \% 5.56 \% 2.52 .75$

$2010.12 .265 .35 \% 5.81 \% 2.83$

$2011.02 .095 .60 \% 6.06 \% 3.053 .25$

$2011.04 .065 .85 \% 6.31 \% 3.33 .5$

$2011.07 .076 .10 \% 6.56 \% 3.053 .25$

$2012.06 .085 .85 \% 6.31 \% 2.83$

From the table can be found in China's central bank deposit and lending rates have been lowered, and the same rate of decline. The deposit interest rate is reduced, the residents' savings are reduced, the consumption increases; the loan interest rate is reduced and the credit scale is expanded. In short, the money supply increases. 
2. China's deposit reserve ratio changes

China 's deposit reserve ratio in 2008 - February 24, 2012 changes

(In percentage)

Time large financial institutions medium and small financial institutions

$08.9 .2517 .50 \% 16.50 \%$

$08.10 .1517 .00 \% 16.00 \%$

$08.12 .516 .00 \% 14.00 \%$

$08.12 .2515 .50 \% 13.50 \%$

$10.1 .1816 .00 \% 13.50 \%$

$10.2 .2516 .50 \% 13.50 \%$

$10.5 .1017 .00 \% \quad 13.50 \%$

$10.11 .1617 .50 \% 14.00 \%$

$10.11 .2918 .00 \% 14.50 \%$

$10.12 .2018 .50 \% 15.00 \%$

$11.1 .2019 .00 \% 15.50 \%$

$11.2 .2419 .50 \% 16.00 \%$

$11.3 .1820 .00 \% 16.50 \%$

$11.4 .2120 .50 \% 17.00 \%$

$11.5 .1821 .00 \% 17.50 \%$

$11.6 .2021 .50 \% 18.00 \%$

$11.12 .521 .00 \% 17.50 \%$

$12.2 .2420 .50 \% 17.00 \%$

Source: NetEase Finance

It can be seen that China's deposit reserve ratio is generally rising trend, the large financial institutions deposit reserve ratio is higher than the small and medium-sized financial institutions, and the gap between the growing. At the same time can be found in early 2009, China's deposit reserve ratio is low, the late growth in the fluctuations, indicating that the central bank in the gradual return of funds, the implementation of sound monetary policy.

\section{Research on the relationship between money supply and economic growth}

British economist Keynes founded the state to intervene in the economy of Keynesian economics. Its economic thinking shows that aggregate demand refers to the total demand for goods and services in the economy and society, and the money supply affects the real economy's output and employment. The view of monetary policy is that the central bank can influence the output by adjusting the money supply to influence the interest rate. As long as the national income or output is less than the level of full employment, the state can increase the demand for money by increasing the money supply to achieve full employment status.

The specific transmission mechanism of money supply to economic growth:

Money supply $\mathrm{M}$ increase $\rightarrow$ real interest rate i decrease $\rightarrow$ increase in investment $\mathrm{I} \rightarrow$ increase in total output $\mathrm{Y}$

Investment:

Analyze the money supply from 2008 to 2012, and the data are from China's relevant statistical yearbook

Phenomenon analysis: From the above chart, we can see that the supply of money and GDP growth is a positive correlation. With the increase in money supply, gross domestic product is also increasing. And from the figure we can find the phenomenon of the supply of money is in line with the country to implement the loose monetary policy.

We believe that China's GDP growth is mainly due to investment, consumption, export this 'troika' pull. The specific analysis is as follows: 
Phenomenon Analysis: Since 2008, we have found that with the increase in the money supply, the central bank's interest rate is the first decline after a slight increase, but the overall downward trend. According to the specific transmission mechanism of money supply to economic growth, when the money supply increases, the actual interest rate level will decline. China's interest rate level basically conforms to the transmission mechanism.

Phenomenon analysis: From the figure we can see that, according to the money supply to the economic growth of the specific transmission mechanism, interest rates can increase the investment increase. When the investment increases, the total output $\mathrm{Y}$ increases. So the other effect is also beginning to produce utility: the increase in total output $\rightarrow$ personal disposable income $\mathrm{Yd}$ increase $\rightarrow$ consumption $\mathrm{C}$ increase $\rightarrow$ total output $\mathrm{Y}$ increase, so the corresponding economic growth, our consumption is also increasing, the economic growth further increases have a positive impact. So the biggest impact on GDP growth is the total capital formation that investment. Followed by a greater impact on GDP growth is the final consumer spending, and finally the contribution of goods and services import and export. The changes in the picture are also more in line with this law.

2008 - 2012 China 's three major demand for domestic GDP growth

Year (year) Final consumption expenditure Increase in gross domestic product (percentage) Growth in gross domestic product (GDP) Growth in gross domestic product (percentage) Import and export of goods and services Increase in gross domestic product (percentage points)

20084.244 .510 .95

$20094.58-8.06-3.54$

20104.495 .50 .42

$20115.264 .44-0.39$

$20124.243 .63-0.25$

From the table, we can also draw the main factor affecting the impact of gross domestic product, the final consumption and investment to promote economic growth, and exports on economic growth is a small but negative side effects. The existence of such a phenomenon on the one hand because of China's double surplus so that the appreciation of the renminbi, inhibiting China's exports, and income growth to a certain extent, to stimulate the increase in imports, the dual role of the net exports to reduce, thereby inhibiting the economy increase. But the total consumption and investment generated by the positive role is greater than the small side effects of exports.

To sum up, the increase in money supply from 2008 to 2012 stimulated economic growth. The relationship between money supply and economic growth is seen as an increase in money supply and an increase in economic output, one of the driving forces of economic growth.

\section{Research on the relationship between money supply and inflation}

Theoretically, the impact of money supply on prices is obvious, too much money, because the actual

Economic growth rate cannot be synchronized with the growth rate of money supply, too much money must be digested by the price rise or the rate of money circulation absorbed in China in recent years in order to eliminate the Asian financial crisis brought about by economic weakness, has been low interest rate policy guidance Economic operation, now facing a new round of economic growth cycle in the inflationary pressures increase. According to Friedman, inflation is a currency phenomenon. '

International CCC indicators generally used to observe the degree of inflation in a country, although it is narrow, including only the final product of the social consumer goods this part, not enough to explain the overall situation, but the data easy to collect, the number of published more Frequently, can quickly and directly reflect the price trends that affect the lives of residents, so we use the consumer price index (C PI) as a measure of inflation.

We can use the theory of money quantity, combined with the theory of money multiplier effect, to verify the relationship between money supply and inflation:

If the theory of money quantity is established, then there are:

$$
\mathrm{Mv}=\mathrm{Py},
$$

In this equation known as the transaction equation, $\mathrm{M}$ represents the money supply; $\mathrm{V}$ represents the currency flow rate; $\mathrm{P}$ shows the general price level; y represents the actual income level.

The two sides of the transaction equation take the natural logarithm of the following formula:

$$
\text { In } \mathrm{M}+\text { In } \mathrm{v}=\text { In } \mathrm{P}+\text { In } \mathrm{y}
$$


If the above equation for the constant deformation, then there are:

$$
\text { In } \mathrm{P}=\text { In } \mathrm{v}+\text { In } \mathrm{M}-\text { In } \mathrm{y}
$$

In the discrete time conditions, the two sides at the same time take the difference between:

$\mathrm{D}(\ln \mathrm{P})=\mathrm{d}(\ln \mathrm{v})+\mathrm{d}(1 \mathrm{n} \mathrm{M})-\mathrm{d}(\operatorname{In} \mathrm{y})$

From the above analysis of the influencing factors of inflation, it can be argued that the change in the price level reflected by inflation is positively related to the changes in the flow rate of money and the supply of money, which is related to the negative change of the real domestic income, which is equal to the change of the velocity of money The sum of the changes in the supply of money minus the actual increase in domestic income.

Using this view, we can see from the above chart can be seen in 2008 to increase the growth of money supply faster than GDP growth, indicating that China during this period due to the increase in money supply led to a certain degree of inflation. CPI growth rate in 2009, a decline, followed by an upward trend in 2012 and declined, thus more verified that China does exist inflation phenomenon.

Comparison of China's GDP, Money Supply, Consumer Price Index and Growth Rate in 2008 - 2012

Year (year) Gross Domestic Product GDP (Billion Yuan) Money Supply M2 (Billion Yuan) Consumer Price Index CPI (Last Year $=100$ ) Gross Domestic Product GDP Growth Rate M2 M2 Year-on-year Growth Rate Consumer Price Index CPI growth rate

$2008314045.43475166 .60105 .909 .60 \% 17.80 \% 5.90 \%$

$2009340902.81606225 .0099 .309 .20 \% 27.70 \%-0.70 \%$

$2010401512.80725851 .80103 .3010 .40 \% 19.70 \% 3.30 \%$

$2011473104.05851590 .90105 .409 .30 \% 13.60 \%$ 5.40\%

$2012519470.10974159 .50102 .607 .70 \% 13.80 \% 2.60 \%$

From the table above, it is clear that the growth in money supply from 2008 to 2012 is faster than GDP growth. We have also proved that a higher rate of money growth over a period of time will lead to inflation. The change rate of C PI in the table is basically consistent with the change trend of GDP real growth rate and M 2 growth rate, but they have a common characteristic: GDP growth changes with M 2 growth change before, C PI changes in the post, That is to say, $\mathrm{C}$ PI is lagging behind the real growth of M 2 and GDP, which is consistent with real life and economic theory.

In summary, China's inflation to a certain extent from the impact of broad money growth rate, a period of higher monetary growth rate is the reason for inflation, only the monetary growth rate eventually fell to close to the level of economic growth, the price can be generally stabilized down.

\section{Conclusions}

Money supply is positively related to economic growth. The growth in money supply from 2008 to 2012 has stimulated China's economic growth. This is due to the increase in the money supply can affect the interest rate, thus affecting the investment, through the multiplier effect eventually increase the total economy. Therefore, the relationship between money supply and economic growth is manifested as an increase in the money supply and an increase in economic output. Therefore, money is one of the driving forces of economic growth.

On the other hand, economic growth on the one hand will stimulate the expansion of money supply, but at the same time will cause the rapid rise in prices. Therefore, the government in the realization of economic growth should control the rate of price increases, to maintain a certain amount of money supply growth rate, timely macro-control, and taking into account the money supply and economic growth on the lagging effect of inflation, monetary authorities and the government should be the size of the situation, and actively seek the money supply and economic growth, social balance of the demand.

Finally, the Chinese government should strengthen the supervision, early warning and forecasting of price, improve and perfect the predictability, appropriateness, enthusiasm, relevance and effectiveness of monetary policy control, and take the initiative to guide the commercial banks and the public to form a reasonable inflation expectations, and thus guide the commercial banks and the public together to economic behavior. The state should actively create a healthy economic and financial environment, improve the financial market, speed up the reform of the financial system, strengthen the central bank's financial macro-control capacity. The monetary authorities should respond in a timely manner before inflation, reduce the lag effect, become passive, take preventive measures, establish early warning mechanisms to control inflation, rather than adjust it after inflation occurs, so that costs will be substantial improve. 


\section{References}

1. Ba Jusong. Economic analysis of the effectiveness of china's monetary policy [M] Beijing: Economic Science Press, 2000. 130-178

2. Cairns, Xu YuNan, translation. Employment interest and currency [M] Beijing: Commercial Press, 1963

3. Mishkin. Monetary Finance [M] Beijing: Renmin University of China Press, 1998.

4. Yi Gang. China's currency, banking and financial markets [M] Shanghai: Shanghai People's Publishing House, 1996.67-190

5. Dai Genyou. China's monetary policy transmission mechanism research [M] Beijing: Economic Science Press, 2001. 189-212

6. Wan Jieqiu, Xu Tao. The endogeneity of money supply and the efficiency of monetary policy. Economic research [J]. 2001 (3) $.34-44$

7. Dai G, on China's monetary policy theory and practice issues. Financial Research [J]. 2000 (09). 3-18

8. [8] Gao Tiemei, Wang Jinming. Dynamic analysis of monetary policy transmission mechanism in China. Financial Research [J]. 2001 (03). 14-23

9. Liu Jinquan. The effectiveness and asymmetry of the role of monetary policy. Managing the World [J]. 2002 (03)

10. [10] Li Yang, Peng Xingyun. Analysis of the Federal Reserve's interest rate policy and its monetary policy philosophy. International financial research [J]. 2005 (02). 28-37

11. Liu Bin. Empirical Study on the relationship between money supply and output and price in China. Financial Research [J]. 2002 (07). 17-30

12. Liu Lin. Money supply, inflation and China's economic growth based on co-integration of empirical analysis. [J], 2005 (03). 34-50

13. Lucas, Munkhoff Norbert, Toksdorf, Liu Li, et al. Financial market changes - the financial sector and the physical economy separated [M]. Beijing: Chinese people University Press, 2005.

14. Sheng Songcheng, Shi Bingchao, Chen Jianan. Modern Monetary Economics M]. Beijing: China Financial Publishing House, 2001.

15. Chen Yanbin, Tang Shilei, Li Du. Money supply can predict China's inflation? [J]. Economic Theory and Economic Management, 2009, (2).

16. [Wang Hongli. China's price trend analysis and its macro-control [J]. World Economy, 2005, (7).

17. He Wentao, Wang Chengjin. Money supply, virtual economy and inflation [J]. Finance and Economics, 2008, (9). 